\section{Australian Journal of \\ Crop Science}

AJCS 15(03):343-347 (2021)

doi: 10.21475/ajcs.21.15.03.p2600
ISSN:1835-2707

\title{
Influence of application of nitrogen doses on the post-harvest quality of cucumber
}

\author{
Adriane Cristina Pereira ${ }^{1}$, Danielle Godinho de Araújo Perfeito ${ }^{1}$, Gabriel Pereira de Souza ${ }^{1}$, Natália \\ Arruda $^{2}$, Cleiton Gredson Sabin Benett ${ }^{3}$, Luciana Maria da Silva ${ }^{3}$ \\ ${ }^{1}$ Goiano Federal Institute (Instituto Federal Goiano), Urutaí Campus, Urutaí-Go, Brazil \\ ${ }^{2}$ Maringá State University (Universidade Estadual de Maringá), Umuarama Campus, Umuarama-PR, Brazil \\ ${ }^{3}$ Goiás State University (Universidade Estadual de Goiás), Ipameri Campus, Ipameri-GO, Brazil
}

\section{*Corresponding author: cleiton.benett@gmail.com}

\begin{abstract}
The conditions of cultivation and the management of fertilization influence the productivity and the post-harvest quality of cucumbers in an expressive way. In this sense, the aim of this study is to evaluate the physical, chemical and sensorial post-harvest quality of cucumbers for canning purposes submitted to different doses of nitrogen fertilization. The experiment was carried out in a greenhouse at the Goiano Federal Institute (IF Goiano), campus Urutaí and After harvest, the material was sent to the food technology laboratory located in the campus. The soil of the area is classified as Red Latosol according he cucumber cultivar used was the Cucumis sativus L. Kybria F1 hybrid, most suitable for the processing of canned foods. The experimental design was randomized blocks and five treatments (nitrogen doses 0, 50, 100, 150 and $200 \mathrm{~kg} \mathrm{ha}^{-1}$ ), and four replications. The physical parameters fruit length and diameter, fruit fresh matter, production per plant, titratable acidity (TA), pH, soluble solids (SS), moisture, ash content, and SS/TA ratio were evaluated. A sensory analysis was performed using acceptance and orderingpreference tests, in addition to an instrumental evaluation of texture. The application of different doses of nitrogen to cucumber in a protected environment influenced the production per plant and the physical-chemical characteristics of the fruits. However, the sensory quality was not affected. The doses 100 and $150 \mathrm{~kg} \mathrm{ha}^{-1}$ of nitrogen is recommended for the production of canned cucumber.
\end{abstract}

Keywords: Cucumis sativus L., sensory analysis, fertilization, physical-chemical, texture.

Abbreviations: N_nitrogen; SS_soluble solids; TA_titratable acidity; SS/TA_soluble solids/titratable acidity.

\section{Introduction}

Cucumber (Cucumis sativus L.) is a plant of the family Cucurbitaceae originating in India. It is a crop of undetermined growth. It presents its best development with high temperature, relative air humidity, luminosity, and a continuous supply of water and nutrients (Amaro et al., 2014). Botanically, the cucumber is a non-climacteric fruit partially developed. The organ that makes up the edible portion of the cultivar is classified as fleshy and immature (Fennema et al., 2010).

The cucumber crop has a great socioeconomic importance for the vegetable agribusiness. It can be eaten raw, in salads, sandwiches, soups, or canned. In addition, it can be used in cosmetics and drugs because of its nutraceutical properties (Carvalho et al., 2013).

The development of the plant is favored by temperatures above 20 으. The cultivation in protected environments favors the control and production of this crop, maintaining favorable conditions for its development and productivity (Sediyama et al., 2014). This vegetable has been cultivated more frequently in protected environments (Sediyama et al., 2012).

The nutritional status of the plant influences biomass production and fruit quality. Eifediyi and Remison (2010) reported that the combination of organic and inorganic fertilization favors production and the physical characteristics length, diameter and mass of cucumbers. Nitrogen $(\mathrm{N})$ influences processes involved in plant growth and development, promoting morphophysiological changes related to photosynthesis, root development and root activity, ionic nutrient uptake, cell growth and cell differentiation (Costa et al. 2015).

Several authors Resende and Flori (2003), Zhang et al. (2011), Kirnak et al. (2005), Agba and Enya (2005) and Dai et al. (2011) has observed the importance of nitrogen fertilization in the productivity and quality of cucumber fruits.

Studies on the application of nutrients to cucumber crops in protected environments are necessary because they may contribute to achieve better results in the cultivation of this vegetable in Brazil by proposing alternatives that help to obtain a higher productivity and quality of fruits.

The objective of the present study is to compare and characterize the physical, chemical and sensory attributes of canned cucumber submitted to different doses of nitrogen fertilization. This study gains relevance due to assessing the influence of crop treatments on the post-harvest quality of fruits and vegetables, and due to the importance of the cucumber culture. 


\section{Results and Discussion}

\section{Physical characteristics}

By analyzing the influence of nitrogen doses on the physical characteristics of cucumber (Table 1), a statistical difference was observed only for production per plant $\left(\mathrm{kg} \mathrm{ha}^{-1}\right)$.

The doses 50,100 and $150 \mathrm{~kg} \mathrm{ha}^{-1}$ of nitrogen provided the best results for production of fruits per plant $\left(\mathrm{kg} \mathrm{ha}^{-1}\right)$, without statistically differing among them. Despite this result, the $\mathrm{N}$ dose $150 \mathrm{~kg} \mathrm{ha}^{-1}$ yielded $1,469.41 \mathrm{~kg} \mathrm{plant}^{-1}$, the highest production obtained. These results are in agreement with those observed by Wahocho et al. (2016), who reported the highest indexes by applying $100-150 \mathrm{~kg} \mathrm{ha}^{-1}$ of nitrogen to plants. Souza et al. (2018) verified an increase in nitrogen fertilization in the cucumber crop for fresh fruit mass and yield per plant.

Fruit length is an important parameter because it strongly affects the total production of cucumber. As the studied crop is intended to producing canned foods, the intention is not to obtain large fruits, rather fruits with a good yield. Therefore, the harvest is carried out close to the anthesis period, different from fruits destined to commercialization in natura, i.e., approximately 25 days after anthesis. In this sense, cucumber for canning must be smaller fruits with a good flavor and the characteristic taste of the canned cucumber.

As expected, nitrogen application in the five treatments did not differ significantly as to length, since this parameter was selected as the standard for cucumber harvesting. However, Jilani et al. (2009) observed positive effects of nitrogen in conjunction with phosphorus and potassium on fruit length and production of hybrid cucumbers (Noble). It is worth mentioning that the cultural traits, the soil characteristics and the cultivar characteristics, besides several other factors, may influence the results obtained by the authors considering the variables of both studies.

As for the other attributes of the physical parameters evaluated, it was also not possible to differentiate the treatments statistically. Regarding fruit diameter, the values obtained are within the standards of cucumber for canning because this variable has a direct relation with length. According to Santos et al. (2014), pickling cucumber can be classified as type I (6-9 cm long) and type II (9-12 cm long). The results obtained in this work are in accordance with this classification.

\section{Physical-chemical characteristics}

In the evaluation of the characteristics $\mathrm{pH}$, titratable acidity (TA), moisture, ash, soluble solids (SS) and SS/TA ratio (Table 2 ), it was possible to observe that there was a significant difference $(p<0.05)$ for all variables analyzed.

By evaluating the influence of nitrogen doses on the $\mathrm{pH}$ of cucumber, it was possible to observe that, when $200 \mathrm{~kg} \mathrm{ha}^{-1}$ of nitrogen were applied, the fruits were neutral. As the doses of nitrogen decreased, the $\mathrm{pH}$ became more acidic. For all treatments, the cucumbers had a $\mathrm{pH}$ higher than 6 , which results in a low fruit acidity. In this case, for the preparation of pickles, it is necessary to reduce the $\mathrm{pH}$ through the acidification of the medium to a $\mathrm{pH}$ lower than 4.5 , which restricts the growth of pathogenic microorganisms, allowing the application of pasteurization as a heat treatment for conservation. By assessing different doses of cover nitrogen and the quality and production of watermelon fruits, Barros et al. (2012) did not verify the influence of doses on the fruit pH. Pedó et al. (2019) observed an increase in $\mathrm{pH}$ combined with an increased frequency of leaf fertilization (Torpedo ) in Physalis.

The determination of total acidity in foods is important to evaluate the processing and the state of conservation of foods. An increase in acidity (TA) was observed according to the increase in nitrogen doses up to $100 \mathrm{~kg} \mathrm{ha}^{-1}$. For the doses 100,150 and $200 \mathrm{~kg} \mathrm{ha}^{-1}$, the values showed no statistical difference $(p<0.05)$. However, Silva et al. (2014), evaluating the influence of nitrogen and potassium doses on the melon crop, observed a lower acid content, varying between 0.25 and $0.40 \%$. Despite belonging to the same family, the titratable acidity of the cucumber is greater than that of melon because the fruits are harvested green and with a more acidic taste.

By evaluating the moisture of cucumber fruits, it was possible to observe a statistical difference for nitrogen doses. The doses 50, 100 and $150 \mathrm{~kg} \mathrm{ha}^{-1}$ presented the highest moisture, and did not differ statistically. The moisture or water content of a food is related to its stability, quality and composition. In addition, the moisture content is strongly related to soluble solids content. Thus, the high moisture content of cucumber, besides causing an apparent reduction in soluble solids, may also influence the composition of the edible part of the fruit. It was observed that the results obtained for moisture were similar (around 95\%) to those listed in the Brazilian Table of Food Composition - Taco (2011), in which the moisture content of the raw cucumber is $96.8 \%$.

The mineral material is the inorganic residue that remains after the burning of the organic matter, which is transformed into $\mathrm{CO}_{2}, \mathrm{H}_{2} \mathrm{O}$ and $\mathrm{NO}_{2}$ (Cecchi, 2003). The minerals in the ashes are metal oxides, sulfates, phosphates, nitrates, chlorides, and other halogenates (Fennema et al., 2010). The nitrogen dose had a significant influence on ash

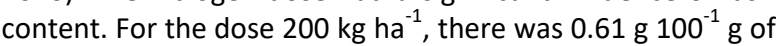
ash. For the dose $150 \mathrm{~kg} \mathrm{ha}^{-1}$ of $\mathrm{N}$, there was only $0.48 \mathrm{~g} \mathrm{100}$ ${ }^{1} \mathrm{~g}$ of ash. The results were slightly higher than the data presented by Taco (2011), which indicates $0.3 \mathrm{~g}$ of ash for raw cucumber

The mean values of soluble solids (SS) were close to $5^{\circ} \mathrm{Brix}$. Choi et al. (2015) observed a $3.5{ }^{\circ}$ Brix SS for freshly harvested cucumbers of the Baegdadagi variety grown in commercial greenhouses in central Korea. This response variation may be associated to different growing environments mainly in terms of temperature and solar radiation, and management practices that influence the accumulation of sugars and organic acids dissolved in fruits. Different substances compose the SS, and sugars are the main constituents of SS in various fruits. The cucumbers present a low sugar concentration and a high acid concentration as they are harvested still immature (Medeiros et al., 2011), which characterizes a crop with fruits with a low ratio.

\section{Instrumental texture}

Firmness is an important characteristic in the evaluation of the quality of a product. It is decisive in the acceptability by the consumer. According to Chitarra and Chitarra (2005), firmness is related to the force necessary for the product to reach a given deformation because of loss of cell turgor and the action of hydrolytic enzymes on the cell wall.

There was no significant difference $(p>0.05)$ in firmness in any of the treatments (Table 3 ) for the three regions of cucumbers (base, equatorial region and tip) in function of nitrogen doses. 
Table 1. Physical characterization of the different treatments of nitrogen fertilization of canned cucumber.

\begin{tabular}{lllll}
\hline Nitrogen dose & Length & Diameter & Production & Fresh matter \\
\hline $\mathrm{kg} \mathrm{ha}^{-1}$ & $(\mathrm{~cm})$ & $(\mathrm{mm})$ & g plant $^{-1}$ & $(\mathrm{~g})$ \\
\hline 0 & $7.43 \mathrm{a}$ & $21.45 \mathrm{a}$ & $638.86 \mathrm{~b}$ & $29.22 \mathrm{a}$ \\
50 & $7.47 \mathrm{a}$ & $21.11 \mathrm{a}$ & $1,151.92 \mathrm{a}$ & $27.44 \mathrm{a}$ \\
100 & $7.44 \mathrm{a}$ & $21.22 \mathrm{a}$ & $1,317.09 \mathrm{a}$ & $20.33 \mathrm{a}$ \\
150 & $7.52 \mathrm{a}$ & $21.95 \mathrm{a}$ & $1,469.41 \mathrm{a}$ & $29.33 \mathrm{a}$ \\
\hline 200 & $7.44 \mathrm{a}$ & $21.28 \mathrm{a}$ & $489.18 \mathrm{~b}$ & $30.44 \mathrm{a}$ \\
\hline F Value & 0.920 & 1.542 & 15.648 & 4.064 \\
\hline CV (\%) & 0.97 & 2.47 & 21.37 & 18.03 \\
\hline
\end{tabular}

Means followed by the same letter do not differ by Tukey test at $5 \%$ probability.

Table 2. Mean values of physical-chemical parameters of different treatments of nitrogen fertilization in cucumber for canning.

\begin{tabular}{|c|c|c|c|c|c|c|}
\hline \multirow{2}{*}{$\begin{array}{l}\text { Nitrogen dose } \\
\mathrm{kg} \mathrm{ha}^{-1}\end{array}$} & \multirow{2}{*}{$\mathrm{pH}$} & TA & Moisture & Ash & \multirow{2}{*}{$\begin{array}{l}\text { SS } \\
\text { (oBrix) } \\
\end{array}$} & \multirow{2}{*}{ Ratio } \\
\hline & & (\% citric acid) & \multicolumn{2}{|c|}{----- $\left(\right.$ g $100^{-1}$ g) ----- } & & \\
\hline 0 & $6.43 \mathrm{~b}$ & $1.09 \mathrm{~b}$ & $94.80 \mathrm{c}$ & $0.58 \mathrm{a}$ & $5.00 \mathrm{a}$ & $4.62 \mathrm{ab}$ \\
\hline 50 & $6.76 \mathrm{ab}$ & $0.96 \mathrm{~b}$ & $95.19 a b$ & $0.59 a$ & $4.90 \mathrm{~b}$ & $5.10 \mathrm{a}$ \\
\hline 100 & $6.70 \mathrm{ab}$ & $1.67 \mathrm{a}$ & $95.48 \mathrm{a}$ & $0.53 a b$ & $4.90 \mathrm{~b}$ & $2.94 \mathrm{c}$ \\
\hline 150 & $6.56 \mathrm{~b}$ & $1.40 a b$ & $95.20 a b$ & $0.48 \mathrm{~b}$ & $4.97 a b$ & $3.64 b c$ \\
\hline 200 & $7.00 \mathrm{a}$ & $1.28 \mathrm{ab}$ & $95.03 \mathrm{bc}$ & $0.61 \mathrm{a}$ & $4.90 \mathrm{~b}$ & $3.85 a b c$ \\
\hline F Value & 9.581 & 7.495 & 14.193 & 8.731 & 10.001 & 8.829 \\
\hline CV (\%) & 1.79 & 13.68 & 0.12 & 5.57 & 0.52 & 12.24 \\
\hline
\end{tabular}

Means followed by the same letter do not differ by Tukey test at $5 \%$ probability.

Table 3. Mean values for firmness ( $\mathrm{N}$ ) of the base, equatorial region and tip of cucumbers for canning in the five treatments.

\begin{tabular}{|c|c|c|c|}
\hline Nitrogen dose & Firmness Base & Firmness Equatorial Region & Firmness Tip \\
\hline $\mathrm{kg} \mathrm{ha}^{-1}$ & \multicolumn{3}{|c|}{ 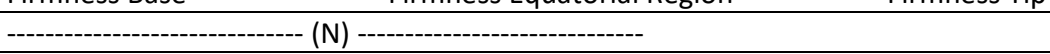 } \\
\hline 0 & $38.8 \mathrm{a}$ & $43.6 \mathrm{a}$ & $42.5 \mathrm{a}$ \\
\hline 50 & $38.6 \mathrm{a}$ & $40.1 \mathrm{a}$ & $35.8 \mathrm{a}$ \\
\hline 100 & $38.6 \mathrm{a}$ & 38.9 a & 35.9 a \\
\hline 150 & $34.5 \mathrm{a}$ & $38.5 \mathrm{a}$ & $31.1 \mathrm{a}$ \\
\hline 200 & $42.3 \mathrm{a}$ & $35.7 \mathrm{a}$ & $36.3 \mathrm{a}$ \\
\hline F Value & 0.859 & 1.352 & 1.637 \\
\hline CV (\%) & 24.36 & 19.81 & 27.76 \\
\hline
\end{tabular}

*Means followed by the same letter do not differ by Tukey test at $5 \%$ probability.

Omoba and Onyekwere (2016) evaluated the firmness of the equatorial region of cucumbers grown in Nigeria, and found force values ranging from 50.5 to $52.5(\mathrm{~N})$, higher than those observed in this work for a variety of cucumbers destined for canning.

\section{Sensory analysis characteristics}

\section{Order-preference test}

According to the comparative evaluation of the appearance of cucumbers referring to the five doses of nitrogen fertilization, there was no difference in preference. Thus, nitrogen fertilization did not influence the preference in relation to fruit appearance.

\section{Acceptance test}

Three sensorial attributes were analyzed to evaluate the acceptability of cucumbers of the five treatments (doses of nitrogen): appearance, taste and texture. There was no statistically significant difference $(p>0.05)$ in relation to the evaluated attributes among the five cucumber samples, that is, the treatments did not influence the sensory acceptance of cucumbers.

According to the scores obtained, the five cucumber samples were accepted. The mean scores of the attribute taste presented values above 6.0 (equivalent to "slightly liked"). The cucumbers obtained a greater sensorial acceptability as for the attributes appearance and texture, with means a score above 7 (equivalent to moderately liked). Souza et al. (2018), evaluating the sensory assessment of pickles of Coccinia grandis under different bleaching times, also obtained averages of acceptance close to 6.5 for the attributes appearance, texture and flavor.

\section{Material and Methods}

\section{Location and experiment}

The experiment was carried out in a greenhouse at the Goiano Federal Institute (IF Goiano), campus Urutaí, at $17^{\circ} 27^{\prime} 49$ "S and $48^{\circ} 12^{\prime} 06^{\prime \prime} \mathrm{W}$ and an average altitude of 744 $\mathrm{m}$. After harvest, the material was sent to the food technology laboratory located in the campus. The climate of the region is Cwa, hot temperate, according to the classification of Köppen-Geiger (Cardoso et al., 2014). The soil of the area is classified as Red Latosol according to Santos et al. (2013). The soil chemical characteristics of the experimental area were determined before the installation of the experiment according to the methodology proposed by Ribeiro et al. (1999). The results for the layer 0.0-0.20 m are $920 \mathrm{mg} \mathrm{dm}^{-3}$ of $\mathrm{P}$ (Mehlich), $23 \mathrm{~g} \mathrm{dm}^{-3}$ of $\mathrm{OM}, \mathrm{pH} 5.7$ $\left(\mathrm{CaCl}_{2}\right), \mathrm{K}, \mathrm{Ca}, \mathrm{Mg}$ and $\mathrm{H}+\mathrm{Al}=8.0,89.0,23.0$ and 16.0 mmolc $\mathrm{dm}^{-3}$, respectively, and base saturation of $88.5 \%$.

The cucumber cultivar used was the Cucumis sativus L. Kybria F1 hybrid, most suitable for the processing of canned foods. The experimental design was randomized blocks and five treatments (nitrogen doses 0,50,100, 150 and $200 \mathrm{~kg}$ 
$\left.\mathrm{ha}^{-1}\right)$, and four replications. The source of nitrogen was urea, and the doses comprised plots at 15, 30 and 45 days after emergence. Each plot comprised ten plants. The four central plants of each plot, at a spacing of $0.2 \mathrm{~m}$ between plants and $0.8 \mathrm{~m}$ between rows, were evaluated.

The greenhouse used in this study was a plant nursery, with dimensions of $6.4 \mathrm{~m} \times 18.0 \mathrm{~m}$ and a height of $4.00 \mathrm{~m}$ under the gutter and $6.00 \mathrm{~m}$ at the peak of the arched cover. The structure was built with galvanized steel arches and was covered with 150- $\mu \mathrm{m}$ reflective polyethylene film. Seeds of the pickling cucumber (Cucumis sativus L.) hybrid Kybria F1 were used, and sowing was performed on $01 / 19 / 2016$ by placing two seeds directly into the planting furrow.

The sowing was performed directly in the furrow, and the irrigation was performed twice a day until the emergence process began. Irrigation management was performed using the drip system and $15 \mathrm{kPa}$, installed in a protected environment. The plants were stacked using the vertical system and wires. The irrigation was performed using the drip system and $15 \mathrm{kPa}$. Two prunings were performed at the heights 0.20 and $0.10 \mathrm{~m}$ when $50 \%$ of the plants reached 0.5 and $1.0 \mathrm{~m}$ in height, respectively. Manual weeding and phytosanitary control were performed to control weeds and pests whenever necessary.

\section{Harvest and physical aspects}

The harvest was performed manually in the first hours of the morning, which are the ideal harvest time as it affects to a lesser extent the biochemical reactions that occur in fruits. For the determination of the ideal harvest point, a visual analysis of fruit size was carried out. The best point is approximately $7-9 \mathrm{~cm}$ in length at 37 days after sowing extending for 36 days.

The fruit length (measured using a ruler graduated in centimeters), fruit diameter (measured using a digital caliper), fresh matter (obtained by weighing the material on a precision scale of $\pm 0.01 \mathrm{~g}$ ) and production per plant (obtained by weighing all fruits harvested during the experiment in each useful plot; the means were expressed as kg.plant ${ }^{-1}$ ) were determined.

\section{Physical-chemical analyses}

To perform the analyses, each treatment was divided into three lots, which represented the replicates, containing five cucumbers selected at random. The fruits were previously crushed in a mixer (Philips Walita, model RI 1364/AB).

The physical-chemical analyses comprised $\mathrm{pH}$ determination using a potentiometer (Digimed DM-20) calibrated with a buffer solution with $\mathrm{pH} 4$ and 7; titratable acidity (TA) by titration in $0.1 \mathrm{M} \mathrm{NaOH}$, and the results expressed as percent of citric acid; soluble solids (SS), determined based on the direct reading of ${ }^{\circ}$ Brix of the sample at $20^{\circ} \mathrm{C}$ using a digital refractometer (LEICA, AR200); moisture, obtained using a Tecnal TE394/1 drying oven with air circulation and ventilation at $85^{\circ} \mathrm{C}$; ash, measured by muffle incineration and calcination at $550^{\circ} \mathrm{C}$; and ratio between soluble solids and titratable acidity. All analyses were performed according to the methodologies of the Association Official Analytical Chemists (AOAC, 2010).

\section{Instrumental texture parameters}

The determinations of instrumental texture parameters of the samples were performed the morning after the cucumber harvesting using a TA-XT2 Plus texture meter (Stable Micro Systems, Surrey, England). Shear force, strain rate of $150 \%$, pre-test speed, and test and post-test speed of $2 \mathrm{~mm} \mathrm{~s}^{-1}$ were applied at $25^{\circ} \mathrm{C}$. The load cell was a guillotine blade. The maximum shear force of the base, equatorial region and tip of each cucumber were evaluated considering the five treatments and the ten replications (ten cucumbers for each treatment).

\section{Sensory analysis}

Immediately after harvesting and evaluation of physical parameters, the fruits were washed in running water, sanitized in sodium hypochlorite $100 \mathrm{mg} \mathrm{L}^{-1}$ for 15 minutes, and finally rinsed in $5 \mathrm{mg} \mathrm{L}^{-1}$ sodium hypochlorite solution.

The sensory analysis of cucumbers was carried out by 40 healthy individuals, nonsmokers, aged $18-40$ years, students and employees of the Goiano Federal Institute, campus Urutaí, with the habit of consuming the evaluated product. The research ethics committee of the Goiano Federal Institute, campus Urutaí, approved the research (CAAE: 53903815.0.0000.0036).

The sensory analysis was conducted at the Sensory Analysis Laboratory of the IF Goiano, campus Urutaí, in two sessions. In session 1, the ordination-preference test was applied; in session 2, the acceptance test was applied. The analyses were carried out in individual booths under a white light. The five cucumber samples were served in disposable plates, coded with random three-digit numbers, in a completely randomized design.

In the ordination-preference test, the five samples (treatments) were presented simultaneously, and the tasters were asked to sort the samples in ascending order of preference based on the attribute appearance.

The acceptance test comprised a structured hedonic scale of nine points ("I greatly disliked" to "I liked it very much"). The consumers tasted approximately 50 grams of each cucumber sample, corresponding to the five treatments, served sliced in a sequential monadic form. The evaluated attributes were appearance, taste, and texture.

\section{Statistical analysis}

The results obtained in the physical and physical-chemical analyses were subjected to analysis of variance ( $F$ test), and initially to polynomial regression analysis. However, because of equation fitting with a low coefficient of determination $\left(R^{2}\right)$ and considering the practical need to discriminate the nitrogen doses that related more variables to productive interest, it was decided to compare the means of the treatments by Tukey test at $5 \%$ probability using the Sanest statistical analysis software (Zonta et al., 1987).

The results obtained in the acceptance test were analyzed by ANOVA, and the means were compared by Tukey test at $5 \%$ probability using the Sensomaker software.

For the results obtained in the order-preference test, the minimum significant difference was calculated based on the order in which the tasters arranged the samples. They were compared by Friedman test (Ferreira et al., 2000).

\section{Conclusions}

The application of different doses of nitrogen to cucumber in a protected environment influenced the production per plant and the physical-chemical characteristics of the fruits. However, the sensory quality was not affected. The doses 100 and $150 \mathrm{~kg} \mathrm{ha}^{-1}$ of nitrogen is recommended for the production of canned cucumber. 


\section{Acknowledgments}

To the Goiano Federal Institute, Campus Urutaí (Instituto Federal Goiano, Campus Urutaí) and the State University of Goiás, Ipameri Campus (Universidade Estadual de Goiás, Campus Ipameri) for support in conduction of the project. To the Group of Study and Research in Plant Science (GEPFi).

This study was financed in part by the Coordenação de Aperfeiçoamento de Pessoal de Nível Superior - Brasil (CAPES) - Finance Code 001 (Convênio no 817164/2015 CAPES/PROAP)

\section{References}

Agba OA, Enya VE (2005) Response of Cucumber Cucumis sativus $L$. to nitrogen in cross river state of nigeria. Global J. Agr. Sciences 4:165-167.

Amaro ACE, Macedo AC, Ramos ARP, Goto R, Ono EO, Rodrigues JD (2014) The use of grafting to improve the net photosynthesis of cucumber. Theor. Exp. Plant Physiol. 26:241-249.

AOAC - Association Official Analytical Chemists (2010) Official Methods of Analysis of AOAC International. (18nd. ed.) Gaithersburg: AOAC.

Barros MM, Araújo WF, Neves LT, Campos AJ, Tosin JM (2012) Produção e qualidade da melancia submetida a adubação nitrogenada. Rev. Bras. Eng. Agrícola e Ambient. 16:1078-1084.

Cardoso MRD, Marcuzzo FFN, Barros JR (2014) Classificação climática de Köppen-Geiger para o Estado de Goiás e o Distrito Federal. ACTA Geográfica. 8(16): 40-55.

Carvalho ADF, Amaro GB, Lopes JF, Vilela NJ, Filho MM, Andrade R (2013) A cultura do pepino. Circular Técnica, Brasília, 1a ed, cap. 113, p. 118.

Cecchi HM (2003) Fundamentos teóricos e práticos em análises de alimentos. (2nd ed.). Campinas: Editora Unicamp, 208p.

Chitarra MIF, Chitarra AB (2005) Pós-colheita de frutas e hortaliças: fisiologia e manuseio. (2nd ed). Lavras: UFLA, $783 p$.

Choi JM, Park MH, Lee JH, Do KR, Choi HJ, Kim JG (2015) Changes of postharvest quality in 'Bagdadagi' cucumber (Cucumis sativus L.) by storage temperature. J Food Nutr Sci. 3:143-147.

Costa, AR da, Rezende R, Freitas PSL de, Gonçalves ACA, Frizzone JA (2015) A cultura da abobrinha italiana (Cucurbita pepo L.) em ambiente protegido utilizando fertirrigação nitrogenada e potássica. Revista Irriga. 20(1): 105-127.

Dai J, Liu S, Zhang W, Xu R, Luo W, Yin X, Han L, Chen S (2011) Quantifying the effects of nitrogen on fruit growth and yield of cucumber crop in greenhouses. Sci Hortic. 130:551-561.

Eifediyi, EK, Remison SU (2010) Growth and yield of cucumber (Cucumis sativus L.) as influenced by farmyard manure and inorganic fertilizer. J Plant Breed. Crop Sci. 2:216-220.

Fennema OR, Damodaran S, Parkin KL (2010) Química de Alimentos de Fennema. (4nd ed). Porto Alegre: Editora Artmed, 900p.

Ferreira VL, Almeida TCA, Pettinelli MLC, Silva MAAP, Chaves JBP, Barbosa EM (2000) Análise sensorial de testes discriminativos e afetivos. Campinas: SBCTA, $127 \mathrm{p}$.
Jilani MS, Bakar A, Waseem K, Kiran M (2009) Effect of different levels of NPK on the growth and yield of Cucumber (Cucumis sativus) under the plastic tunnel. J Agric Soc Sci. 5:99-101.

Kirnak H, Higgs D, Kaya C, Tas I (2005) Effects of irrigation and nitrogen rates on growth, yield, and quality of muskmelon in semiarid regions. J. Plant Nutr. 28:621-638.

Medeiros PR, Duarte SN, Dias CT, Silva MF (2011) Tolerância do pepino à salinidade em ambiente protegido: efeitos sobre propriedades físico-químicas dos frutos. Irriga. 15:301-311.

Omoba OS, Onyekwere U (2016) Postharvest physicochemical properties of cucumber fruits (Cucumber sativus L) treated with chitosan-lemon grass extracts under different storage durations. Afr J Biotechnol. 15:2758-2766.

Pedó T, Carvalho IR, Szareski VJ, Troyack C, Pimentel JR, Escarela RAV, Silva FL, Peter M, Armonde TZ, Oliveira LC, Vilela FA, Nora L, Mauch CR (2019) Physiological growth attributes, productivity, chemical quality of the fruits of physalis peruviana under a foliar mineral Supplementation. J Agric Sci. 11:561-568.

Ribeiro AC, Guimarães PTG, Alvarez VH (1999) Recomendações para o uso de corretivos e fertilizantes em Minas Gerais - 5a aproximação. Viçosa-MG: UFV. 359p.

Santos ER, Salgado FHM, de Cerqueira AP, Pereira PR, Nascimento IR (2014) Produção de pepino tipo conserva em função de doses de fósforo. Nucleus, 11:403-408.

Sediyama MAN, Nascimento JLM, Lopes IPC, Lima PC, Vidigal SM (2014) Tipos de poda em pepino dos grupos aodai, japonês e caipira. Hort Bras. 32:491-496.

Sediyama MAN, Nascimento JLM, Santos MR, Vidigal SM, Carvalho IPL (2012) Produção de pepino tipo japonês em ambiente protegido em função de adubação orgânica. Rev Bras Agrop Sustentável. 2:65-74.

Silva MC, Silva TJA, Bonfim Silva EM, Farias LN (2014) Características produtivas e qualitativas de melão rendilhado adubado com nitrogênio e potássio. Rev Bras Eng Agríc. 18:581-587.

Souza GP, Borges IA, Benett CGS, Salomão LC, Perfeito DGA (2018) Nitrogen fertilization and different crop management practices in pickling cucumber (Cucumis sativus L.). Aust J Crop Sci. 12:1603-1608.

Souza T, Costa CA, Chauca MNC (2018) Influence of the heat treatment on the quality of ivy gourd (Coccinia grandis). Hort Bras. 36:126-129.

Taco. (2011). Tabela Brasileira de Composição de Alimentos (TACO). (4nd. Ed). Campinas, SP: NEPA-UNICAMP, 113p.

Wahocho NA, Kakar MI, Miano TF, Memon NN, Baloch QB, Talpur KH, Rajput L (2016) Growth and yield of cucumber (Cucumis sativus L.) cultivars in response to different nitrogen levels. Sci Int. 28:2691-2695.

Zhang He-Xi, Chi Dao-Cai, Wang Qun, Fang Jun, Fang Xiao-Yu (2011) Yield and quality response of cucumber to irrigation and nitrogen fertilization under subsurface drip irrigation in solar greenhouse. Agr Sci China 10:921-930.

Zonta EP, Machado AA, Silveira Júnior P (1987) Sistema de análise estatística para microcomputadores: Manual de utilização. (2nd ed). Pelotas-RS: UFPEL. 